\title{
An evaluation on regional differences in the level of carbon finance
}

\author{
Yunzhe Liu \\ International Economy and Trade Institution, Jilin University of Finance and Economics, Changchun 130000, China
}

\begin{abstract}
This paper constructs a carbon financial development index to measure the development level of China's various provinces and regions. It makes a comparative analysis of the general situation and trends of China's carbon finance development to investigate the reasons for restricting the level of the development of carbon finance, then put forward suggestions in policy to improve the development level of China's Carbon Finance.
\end{abstract}

\section{Introduction}

Carbon trading has developed all over the world. The European Union and the United States have formed a relatively complete carbon trading system. At the same time, Japan has completed the pilot work of carbon trading and India can also trade carbon financial derivatives. Countries around the world are competing for the international carbon trading market. China, as a provider of CDM, has great potential in the developing carbon finance. At present, China has carried out carbon trading pilot projects in seven areas such as Shanghai, Tianjin, Beijing and other regions. The banking industry began to implement green credit to reduce the credit for the enterprises of high emission, high energy consuming and high polluting. At the same time, to give credit discount for the enterprises with environmental protection and new energy .Some banks have developed carbon financial products. However, China's carbon practice are low in efficiency and the unbalanced on development in various regions because the financial trading platform is fragmented, the intermediary market is not perfect and there lack of relating policies and regulations.

\section{Comparison on the regional carbon finance development level}

\subsection{Index system for the development of carbon finance}

The measurement index system of the development level of carbon finance is built according to the level, and is divided into three levels. The evaluation index of the development level of carbon finance includes Indicators of economic development indicators of financial environment, indicators of financial efficiency, indicators of financial products, indicators of carbon finance business, indicators of energy efficiency, indicators of science and technology and indicators of policies and regulations.

\subsection{Evaluation on the provincial carbon finace index}

The data of this paper comes from the China Statistical Yearbook, China energy statistical yearbook, Financial Statistical Yearbook it makes 30 provinces in China as the research objects, for China is divided into the west region of 12 provinces, the middle region of 8 provinces and 11 in the East (Tibet is not included for the non availability of some data in Tibet). The data were processed with positive and non quantitative approach and the weight of the index is determined .The carbon finance development level of 30 provinces of China in 2007 and 2012 were analyzed and compared based on hierarchy processing and with the help of Excel and MATLAB.

\subsection{Comparison on the regional carbon finance development level}

It is found that the development level of carbon finance in the provinces of China has been enhanced, but the rate of increase is different (see Table 1). Beijing's carbon financial development level increased significantly. That is because the service industry in Beiing is more developed and Beijing is in the late stage of industrialization and urbanization, thus the energy consumption of the industry is relatively low. Especially Beijing has taken active actions in terms of energy saving, emission reduction, industrial structure adjusting and optimizing the credit structure. The financial system is relatively sound and the carbon financial market is more developed in Beijing which can give full play to the capital oriented role of finance. The development level of carbon finance in Shanxi lags behind the other provinces,

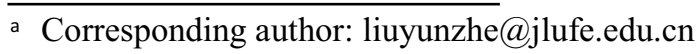


because this area is the main Coal distribution area, and the energy consumption in the coal industry accounted for very high proportion due to the high energy consumption industry such as coal, chemistry, building materials, electric power, metallurgy; In addition, forest the coverage rate is low in the Shanxi Loess Plateau leading to poor ability to offsetting the carbon emissions which makes the carbon finance development level of Shanxi lower than other provinces.

Table 1. China provincial carbon fiance index of year 2007/2012.

\begin{tabular}{|c|c|c|c|c|}
\hline Provinces & Year 2007 & Ranking & Year 2012 & Ranking \\
\hline Beijing & 69.3126 & 1 & 98.7923 & 1 \\
\hline Tianjin & 19.1325 & 6 & 32.5646 & 5 \\
\hline Hebei & 4.7832 & 28 & 7.4215 & 27 \\
\hline Liaoning & 6.8978 & 22 & 11.1056 & 22 \\
\hline Shanghai & 34.4872 & 2 & 47.8823 & 2 \\
\hline Jiangsu & 17.7954 & 8 & 26.1042 & 8 \\
\hline Zhejiang & 26.9801 & 4 & 39.1728 & 3 \\
\hline Fujian & 22.3752 & 5 & 27.7321 & 6 \\
\hline Shandong & 7.7231 & 19 & 11.2122 & 21 \\
\hline Guangdong & 27.8776 & 3 & 37.3324 & 4 \\
\hline Hainan & 11.9211 & 14 & 18.5155 & 11 \\
\hline Shanxi & 1.9786 & 30 & 6.1023 & 29 \\
\hline Jilin & 10.0769 & 17 & 12.5713 & 19 \\
\hline Heilongjiang & 5.8653 & 24 & 9.4821 & 24 \\
\hline Anhui & 12.2657 & 12 & 13.6612 & 17 \\
\hline Jiangxi & 10.6038 & 16 & 18.2344 & 12 \\
\hline Henan & 5.7563 & 25 & 8.2671 & 26 \\
\hline Hebei & 12.9087 & 11 & 17.2621 & 14 \\
\hline Hunan & 11.5432 & 15 & 17.7821 & 13 \\
\hline Inner Mongolia & 2.859 & 29 & 5.7865 & 30 \\
\hline Guangxi & 16.5061 & 9 & 22.7562 & 9 \\
\hline Chongqing & 18.3121 & 7 & 27.4013 & 7 \\
\hline Sichuan & 15.1675 & 10 & 21.1673 & 10 \\
\hline Guizhou & 7.2765 & 21 & 12.7324 & 18 \\
\hline Yunnan & 12.1776 & 13 & 17.1782 & 15 \\
\hline Shanxi & 7.5076 & 20 & 12.5122 & 20 \\
\hline Gansu & 6.9076 & 23 & 10.8448 & 23 \\
\hline Qinghai & 9.6021 & 18 & 15.2512 & 16 \\
\hline Xingxia & 5.1231 & 27 & 8.7521 & 25 \\
\hline Xinjiang & 5.5031 & 26 & 6.7223 & 28 \\
\hline
\end{tabular}

From the rankings of the provinces, most of the provinces ranking in 2012 almost remain unchanged compared with that in 2007. Hainan, Jiangxi, Hunan have been advance constantly, while Anhui and Xinjiang dropped, indicating Hainan has developed toward low-carbon favorably, while Anhui and Xinjiang advanced very slowly in the process of low carbonization .

The top five provinces are Beijing, Shanghai, Zhejiang, Guangdong and Fujian; the last five provinces are Xinjiang, Hebei, Ningxia, Inner Mongolia and Shanxi.
The industry structure of Shanxi and Hebei is not low carbon because these two provinces are typical resource-based cities who are rich in energy but low in efficiency; Inner Mongolia, Ningxia and Xinjiang belong to the western region thus they lack of human resources and are backward in education and imperfect in market system and weak in infrastructure . All these factors make the function of the market allocation of resources in the regions difficult to play, the efficiency of capital not high, role of financial development to promote the economic 
growth and the adjustment of industrial structure remain very limited.

\section{Conclusion and suggestions}

The overall development level of China's carbon finance is relatively backward. The research shows that the industrial structure adjustment, energy intensity change, innovation ability, clean technology level and policy incentive have great impact on carbon finance. Therefore, China's carbon financial development should focus on regional coordination to promote the development of China's carbon finance. We make the following suggestions.

First, to actively cultivate low carbon industry. Ecological agriculture and organic agriculture with the characteristics of circular economy should be vigorously developed; the energy structure of the second industry should be adjusted and the renewable energy should be promoted. The green service industry should be developed to environmental protection industry cycle chain.

Second, to reduce energy intensity accordingly. On one hand, coal energy should be reduced and renewable energy should be developed in the energy based cities. On the other hand, the clean energy and green energy, should be researched and diversified energy consumption system should be established.

Third, to provide technology support and capital support. The national relevant departments should establish the platforms to provide service for the key common technology innovation and the application of scientific and technological achievements to promote international cooperation in the field of low carbon technology. The government should set up special funds to provide financial support for low carbon technology innovation and establish a new information communication system to speed up the disclosure of relative information.

Fourth, to develop the carbon trading market and innovative the carbon trading products. Various types of financial derivative products should be encouraged to improve the carbon financial system and support the low carbon industry and low carbon finance development.

\section{Acknowledgment}

This work was supported by a grant from the Jilin University of Finance and Economics Doctoral Program 2016 No.2016B20.

\section{References}

1. A. S. Malik, Economic Inquiry. 30, 161-173 (1996).

2. F. Jotzo, A. Michaelowa, Climate Policy. 179-196 (2002).

3. C.S. Xie, X. Xu, W.T. Hou, Included in IEEE. 978-1-4244-7161-4 /10 (2010).

4. Y.Z. Liu, Inquiry into Economics Issues. 7, 118-123 (2014).

5. Q. Wang, S. Wang, Social Science Journal. (2014).

6. W.L. Zhang, H. Hu, Journal of Fudan University (Natural Science). 19-21 (2010).

7. Q.M. Liang, Y.M. Wei, Y. Fan, Journal of management. 1, 62-67 (2004).

8. S.Y. Chen, Economic Research. 41-55 (2009).

9. J. Zhu, Hu Nan University (2012).

10. W.L. Zhang, H. Hu, Journal of Tsinghua University (Philosophy and Social Science). 5, 143-150 (2012). 